\title{
Effect of Sodium Nitroprusside on Vase Life and Postharvest Quality of a Cut Rose Cultivar (Rosa hybrida 'Utopia')
}

\author{
Maryam Seyf ${ }^{1}$, Ahmad Khalighi $^{2}$, Younes Mostofi ${ }^{2}, \&$ Roohangiz Naderi ${ }^{2}$ \\ ${ }^{1}$ Graduate Ph.D Student of Department of Horticultural Science, Science and Research Branch, Islamic Azad \\ University, Tehran, Iran \\ ${ }^{2}$ Department of Horticultural Science, Faculty of Agriculture \& Natural Resources, University of Tehran, Karaj, \\ Iran \\ Correspondence: Maryam Seyf, Graduate Ph.D Student of Department of Horticultural Science, Science and \\ Research Branch, Islamic Azad University, Tehran, Iran. Tel: 98-912-337-4510. E-mail: \\ maryam.seyf_horti@yahoo.com
}

Received: September 7, 2012 Accepted: September 14, 2012 Online Published: November 15, 2012

doi:10.5539/jas.v4n12p174 URL: http://dx.doi.org/10.5539/jas.v4n12p174

\begin{abstract}
This experiment was carried out to investigate the effect of sodium nitroprusside (SNP) as a nitric oxide (NO) donor compound on postharvest life of a cut rose cultivar (Rosa hybrida 'Utopia'). At laboratory with $21 \pm 2{ }^{\circ} \mathrm{C}$ temperature, $70 \%$ relative humidity, and $12 \mathrm{~h}$ photoperiod, flowers were treated with SNP $(0$ (Control $=$ Distilled water), (50 and $100 \mu$ Molar) solutions for 24 hours and then were transferred to distilled water and were held in distilled water until the end of the vase life. Soluble protein content, solution uptake rate, relative fresh weight, total chlorophyll $(\mathrm{a}+\mathrm{b})$ content, and vase life of flowers were determined. Results showed that flowers treated with $50 \mu$ Molar SNP had more soluble protein content compared to control. SNP (50 $\mu$ Molar) application increased solution uptake rate of flower stems. Also flowers treated with $50 \mu$ Molar SNP had more relative fresh weight compared to control significantly. SNP (50 $\mu$ Molar) increased vase life of cut rose 'Utopia' from 11 days (control) to 13.3 days.
\end{abstract}

Keywords: nitric oxide, solution uptake, soluble protein, relative fresh weight, total chlorophyll content

\section{Introduction}

Short vase life and postharvest senescence are major problems of cut flowers export and trade. Recently various chemicals have been used to extend the postharvest life of cut flowers. These chemicals are effective on various ways. Preservative solutions are used to lengthen the vase life of cut roses. Some of these compounds slowdown physiological processes, thus delaying senescence, while others reduce transpiration, diminish bacterial growth, and enhance water uptake (Särkkä, 2005). One of the major reasons of short vase life of cut flowers is water stress. Water stress induces premature senescence, bent neck, and wilting (Halvey \& Mayak, 1979). Protein content of petals reduces during the senescence of cut flowers (Gulzar et al., 2005; Halvey \& Mayak, 1979). It occurs due to less protein production and more protein degradation. Soluble proteins decrease during flower opening and senescence (Gulzar et al., 2005). Protein is one of the secondary respiration precursors. Depletion of essential precursors induces flower senescence (Halvey \& Mayak, 1981). Yellowing of the leaves is one of the senescence signs in cut flowers. The onset of yellowing is associated with chlorophyll breakdown (Ferrante et al., 2002). During the senescence process chlorophylase causes to a and b chlorophylls break down. Ethylene has a very important role on postharvest life of some cut flowers by accelerating the senescence and decreasing the vase life (Finger et al., 1999; Hashemabadi \& Gholampour, 2006; Ichimura et al., 2002; Jones et al., 2001; Mayers et al., 1997; Serek et al., 2006). Silver thiosulfate (STS) is an anti ethylene compound that suppresses endogenous ethylene production (Bowyer \& Wills, 2003; Bowyer et al., 2003). Commercial use of STS has been limited because of concerns have been raised over the use of silver as it is a heavy metal salt and environmental toxin and many countries are actively working towards its elimination from commercial use (Badiyan et al., 2004; Bowyer \& Wills, 2003; Bowyer et al., 2003).

1-Methylcyclopropene (1-MCP) has been found to inhibit the action of ethylene (Bowyer et al., 2003; Ichimura et al., 2002). 1-MCP is considered nontoxic to human (Bowyer et al., 2003; Heyes \& Johnston, 1998) but the gaseous nature of this compound is a barrier to its commercial usage (Bowyer \& Wills, 2003). 
Nitric oxide (NO) is a chemical that has been used to extend postharvest life of horticultural products especially cut flowers in recent years. It seems that NO can be a novel substitute for some other toxic chemicals like STS in postharvest technology. NO is a gaseous and highly unstable free radical. It is one of the smallest diatomic molecules with a high diffusivity $\left(4.8 \times 10^{-5} \mathrm{~cm}^{2} \mathrm{~s}^{-1}\right.$ in $\left.\mathrm{H}_{2} \mathrm{O}\right)$ exhibiting hydrophobic properties (Thomas et al., 2008). NO not only easily migrates in the hydrophilic regions of the cell such as cytoplasm, but also freely diffuses through the lipid phase of membranes (Arasimowicz \& Floryszak-Wieczorek, 2007). NO is a widespread signaling molecule in mammals (Del Rio et al., 2004). The NO emission from plants has been known recently. Nitric oxide is synthesized by nitric oxide synthase, nitrate redoctase and non-enzymatic sources in plants (Crawford, 2006; Steven et al., 2003). No is a bioactive molecule that exerts a number of diverse signal functions (Tongfei et al., 2011). This multifunctional plant signal molecule plays role in diverse plant processes including senescence (Bowyer et al., 2003; Del Rio et al., 2004; Rudell \& Matheis, 2006; Sankhla et al., 2005), stomatal closure and aperture (Bowyer et al., 2003; Cevahir et al., 2007; Garcia \& Lamattina, 2003; Rudell \& Matheis, 2006), chlorophyll production and anthocyanin biosynthesis (Bowyer \& Wills, 2003), plant growth and development (Bowyer \& Wills, 2003; Del Rio et al., 2004), plant defense signal against pathogen infection (Del Rio et al., 2004; Rudell \& Matheis, 2006), plant death, regulation of ion channels of guard cells, mitochondrial and chloroplastic functionality (Del Rio et al., 2004), seed germination (Bowyer \& Wills, 2003; Rudell \& Matheis, 2006; Cevahir et al., 2007), hypocotyl elongation, xylem differentiation (Rudell \& Matheis, 2006), root development (Bowyer \& Wills, 2003; Rudell \& Matheis, 2006), regulation of photosynthesis and fruit ripening (Rudell \& Matheis, 2006). NO has some interactions with phytohormones. The interaction between NO and ethylene during the maturation and senescence of plant tissues suggested an antagonistic action of two gases (Del Rio et al., 2004). It was postulated that ethylene production in growing plants may be regulated by NO. NO inhibits ethylene action and synthesis in higher plants (Leshem \& Wills, 1998). It has been suggested that NO acts as a natural senescence delaying plant growth regulator primarily by down regulating of ethylene production (Sankhla et al., 2005). NO free radical, decreases ethylene biosynthesis by oxidative inactivating of ACC synthase (ACS) and ACC oxidase (ACO) co-factors and extends longevity of cut flowers (Leshem \& Wills, 1998). NO could be a novel means of postharvest control to maximize shelf life of fruits, vegetables and flowers. In recent years, many research reports have shown that NO at a low concentration can effectively extend postharvest life of various fruits (Tongfei et al., 2011). The NO effect may be either due to the effect of NO on ethylene production or may represent an action of NO that is independent of ethylene metabolism (Sankhla et al., 2003). NO is applied as fumigation and NO donor compounds to extend the postharvest life of cut flowers (Sankhla et al., 2003; Wills et al., 2003). Fumigation with gaseous NO has been shown effective to extend the postharvest life of a variety of flowers, fruits and vegetables when applied as a short term treatment (Badiyan et al., 2004; Soegiarto et al., 2003; Wills et al., 2003). NO fumigation for 2 hours extended postharvest life of mushroom and geraldton wax flower more than $50 \%$ and lemon more than $100 \%$ (Wills et al., 2003). Also fumigation with NO $\left(10 \mu \mathrm{LL}^{-1}\right)$ for 2 hours increased postharvest life of strawberries (Wills et al., 2000). However the gaseous nature of this compound is a barrier to its commercial usage (Badiyan et al., 2004; Bowyer \& Wills, 2003). NO donors are solid compounds that store NO chemically but allow it to be regenerated under appropriate physical conditions (Badiyan et al., 2004; Bowyer \& Wills, 2003; Bowyer et al., 2003). There are some NO donor compounds that used for elongation of postharvest life of horticultural productions specially cut flowers like DETA/NO (2,2-(Hydroxynitrosohydrazino)-bisethanamine), SNAP (S-Nitros-N-acetylpenicilamine), PBN (N-Butil- $\alpha^{\prime}$-phenil nitrone), Sin-1 (3-mopholinosil-nonomine), and Sodium nitroprusside (Leshem \& Wills, 1998; Wills et al., 2004). Sodium nitroprusside (SNP) is the most common compound among NO donor compounds (Steven et al., 2003). Nitroprusside is an anion that is available as a sodium dehydrate salt $\mathrm{Na}_{2}\left[\mathrm{Fe}(\mathrm{CN})_{5} \mathrm{NO}_{3} \mathrm{H}_{2} \mathrm{O}\right.$. This red solid compound is water soluble and less alcohol soluble (Butler \& Megson, 2002). There are some reports about positive effect of NO donor application on cut flowers. DETA/NO $\left(10 \mathrm{mgL}^{-1}\right)$ increased vase life of gerbera $200 \%$, tulip and iris $50 \%$, snapdragon, delphinium and oriental lily $40 \%$, rose $20 \%$ and chrysanthemum $10 \%$ (Badiyan et al., 2004). Also DETA/NO (10 mg/L) extended carnation (White Sim cultivar) postharvest life about 50\% (Bowyer et al., 2003). This chemical $(10,100,1000 \mathrm{ppm})$ increased postharvest life of some flowers like ptilotus $(40 \%)$, kangaroo paw (34\%), and waratah (22\%) (Bowyer \& Wills, 2003). SNP has been used in some experiments to extend the postharvest life of cut flowers. The positive effect of SNP on postharvest life of cut lupine flowers has been reported previously (Sankhla et al., 2005). In another experiment SNP (50 and $100 \mu$ Molar) extended vase life of carnation cut flowers (Mostofi et al., 2010).

There is not any report about the application of SNP on cut roses. Rose is the most important cut flower in the world and it is necessary to find a substitute chemical for STS and other environmental toxin compounds to extend the postharvest life of roses.

In this experiment, effect of SNP as a NO donor compound was studied on vase life of cut rose flower 'Utopia'. 


\section{Material and Methods}

Cut rose flowers (Rosa hybrida cv.Utopia) were obtained from a commercial greenhouse in Yazd, Iran. Flowers were harvested in the morning and were transported to laboratory in Tehran by plane immediately. Flower stem ends were recut under water to remove air emboli and to prevent vascular blockage. All flower stems were in the same length of $45 \mathrm{~cm}$ after recutting. Flowers were treated on the basis of factorial design with three factors and four replications. The least significant difference (LSD at $P=0.01$ ) was used to compare differences between means.

SNP was used as a NO donor compound. This red solid compound was dissolved in distilled water in concentrations of 50 and $100 \mu$ Molar $(\mu \mathrm{M})$. Distilled water was used as control treatment $(0 \mu$ Molar). The solution was applied immediately because of its short Half-life. Four stems were placed in each $500 \mathrm{~mL}$ flask. Flask heads and the gaps around the stems were sealed by foil and pliable putty to prevent contact between NO gas escaping from the solution and the flower heads. Also, whole outer surface of flasks were covered by foil. Flowers were held in solutions at laboratory for $24 \mathrm{~h}$ to permit compound uptake by stems. After this period, flower stems were transferred to distilled water and were held in distilled water until the end of vase life. At the experimental period, the temperature was $21 \pm 2^{\circ} \mathrm{C}$, relative humidity was about $70 \%$, and a $12 \mathrm{~h}$ photoperiod was maintained using fluorescent lamps. Vase life was recorded as the number of days after harvest that flowers reached the end of their longevity due to bent neck or advanced signs of fading on all petals (Liao et al., 2000; Chamani et al., 2005). Solution uptake rate was determined as the ratio of absorbed solution by flower and primary fresh weight of the flower stem. Relative fresh weight of stems was calculated as a ratio of stems fresh weight on each evaluation and their primary fresh weight that have been represented in percentage. (Chamani et al., 2005). The soluble protein concentration was evaluated by Bradford method. For protein extraction $0.1 \mathrm{~g}$ petal specimens were used. All of the extraction process was done in an ice container to prevent protein degradation. Tris-HCl buffer was used for protein extraction. After centrifuging of protein extracts, supernatants were separated and pipetted to test tubes. The buffer (Tris- $\mathrm{HCl}$ ) and protein reagent (Coomassie Brilliant Blue G-250) were added to the test tubes. The absorbance at $595 \mathrm{~nm}$ was measured after 2 minutes by spectrophotometer (Bradford, 1976). For total chlorophyll $(\mathrm{a}+\mathrm{b})$ content determination $0.5 \mathrm{~g}$ leaf specimens were used. Acetone $(80 \%)$ was used for chlorophyll extraction. After centrifuging the extracts, the absorbance were determined in two wave lengths 645 and $663 \mathrm{~nm}$ by spectrophotometer to calculate total chlorophyll content of leaves (Mostofi et al., 2010).

\section{Results and Discussion}

Cut rose flowers 'Utopia' treated with 50 and $100 \mu$ Molar SNP had more soluble protein content compare to control on $10^{\text {th }}$ day. $100 \mu$ Molar SNP treatment had not significant superiority to control at last evaluation. On the other hand, SNP $(50 \mu$ Molar) treatment showed more soluble protein content than control and SNP (100 $\mu$ Molar) on $13^{\text {th }}$ day (Figure 1). In a previous experiment application of DETA/NO $(10 \mathrm{mmol})$ as a NO donor compound did not have any effect on soluble protein content of cut rose 'First red' (Chamani, 2005). Ineffectiveness of SNP (100 $\mu$ Molar) on soluble protein content is due to the high concentration of this solution, because the effect of NO vary depend on its concentration and in many cut flowers and even in fruits low concentrations were more beneficial to extend postharvest life of the product (Sankhla et al., 2005; Wills et al., 2004; Wills et al., 2003). The rate of solution uptake was measured during the experimental period immediately following the $24 \mathrm{hr}$ SNP treatment. In all treatment levels solution uptake by flower stems increased at the $3^{\text {rd }}$ day and then diminished until the end of experiments. From the $9^{\text {th }}$ day until the end of evaluations flowers treated with SNP (50 $\mu$ Molar) showed more solution uptake compare to control and SNP $(100 \mu$ Molar). There were no significant differences among flowers held in distilled water (control) and SNP (100 $\mu$ Molar) solution (Figure 2). There are some reports about ineffectiveness of NO donors on solution uptake rate. Results of a similar study showed that DETA/NO (10, 100 and $1000 \mathrm{ppm}$ ) application did not have significant effect on solution uptake of seven species of native Australian cut flowers such as grevillea, geraldton wax, isopogon, kangaroo paw, waratah, backhousia, and ptilotus. The absence of measurable differences in solution uptake rates in SNP (100 $\mu$ Molar) and control suggests it may be a stress induced response that is countered through nitric oxide metabolism as found in other plant tissues (Bowyer et al., 2003; Corpas et al., 2001; Garcia \& Lamattina, 2003).

SNP $\left(50 \mu\right.$ Molar) treated flowers had significant more relative fresh weight compare to control from $7^{\text {th }}$ day until the last evaluation. Also at two last evaluations SNP (50 $\mu$ Molar) showed more relative fresh weight than SNP $\left(100 \mu\right.$ Molar). The difference between control and SNP (100 $\mu$ Molar) was significant at $13^{\text {th }}$ day (Table 1$)$. The positive effect of NO on relative fresh weight had been shown in other experiment by application of DETA/NO on cut rose 'First Red' (Chamani, 2005). Higher values of relative fresh weight in SNP (50 $\mu$ Molar) treated flowers compared to control is related to effect of this compound on stomata closure and depletion of transpiration rate and water loss. Role of NO in regulation of ion channels of guard cells (Serek \& Reid, 1997) and stomata aperture and 
closure were demonstrated previously (Bowyer et al., 2003; Cevahir et al., 2007; Garcia \& Lamattina, 2003; Rudell \& Matheis, 2006). Application of NO donors decrease opening of stomas and transpiration (Garello et al., 1995). On the other hand, more solution uptake by SNP (50 $\mu$ Molar) treated flowers caused to raise the fresh weight of flowers.

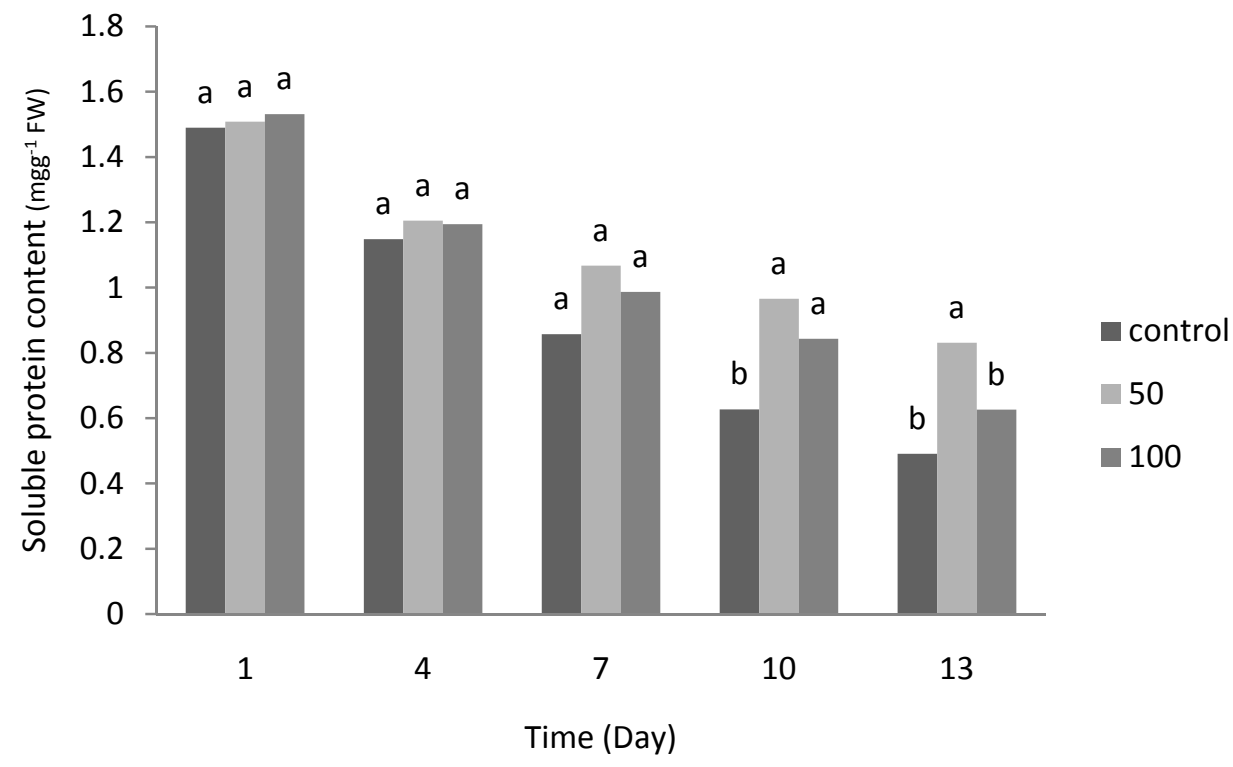

Figure 1. Effect of SNP (control=0, 50, and $100 \mu$ Molar) on soluble protein content $\left(\mathrm{mg} \mathrm{g}^{-1} \mathrm{FW}\right)$ of petals in cut rose 'Utopia'

Values are the means of 4 replicates. Least significant difference (LSD P=0.01) was used to compare differences between means. Same letters in each day show that there are not significant differences among treatment levels.

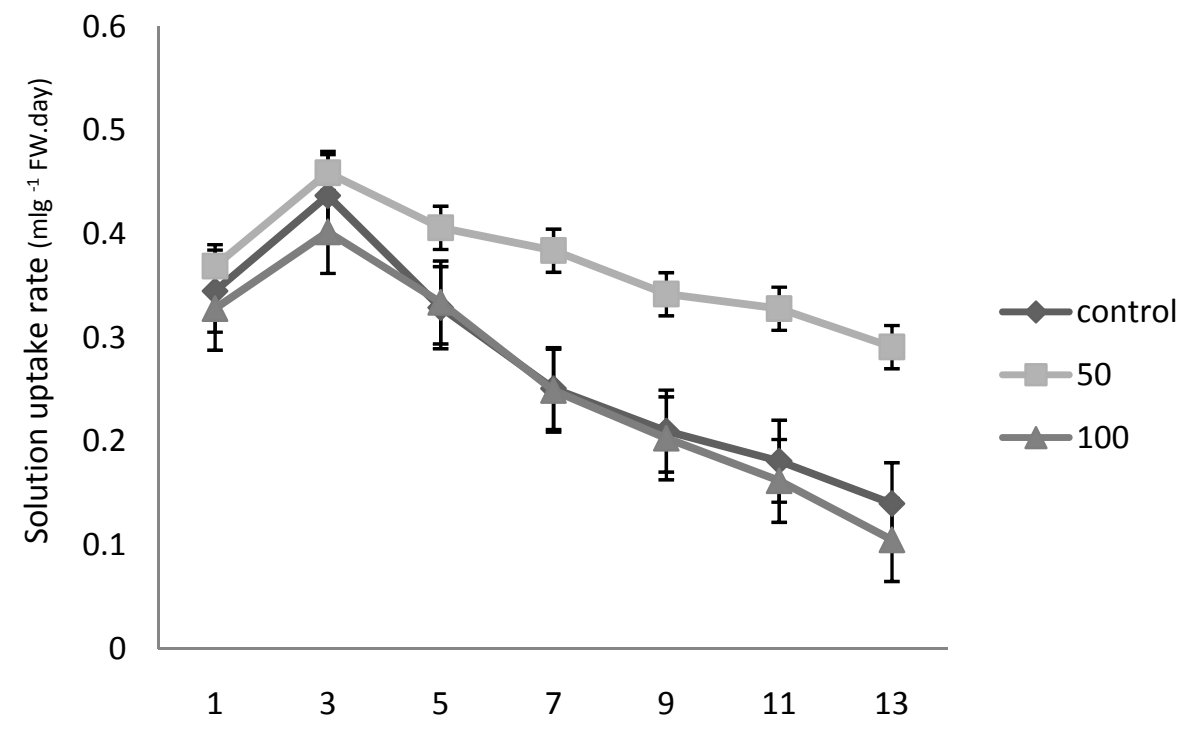

Figure 2. Effect of SNP (control= 0, 50, and $100 \mu$ Molar) on solution uptake rate (ml g-1FW.day) of cut rose 'Utopia'

Values are the means of 4 replicates. Vertical bars represent the standard errors. 
Table1. Effect of SNP on relative fresh weight (\%) of cut rose 'Utopia'

\begin{tabular}{cccccccc}
\hline SNP & \multicolumn{7}{c}{ Time (Day) } \\
\cline { 2 - 8 }$(\mu \mathrm{mol})$ & 1 & 3 & 5 & 7 & 9 & 11 & 13 \\
\hline Control $(0)$ & $99.0^{\mathrm{a}}$ & $92.2^{\mathrm{a}}$ & $84.4^{\mathrm{a}}$ & $69.3^{\mathrm{b}}$ & $54.5^{\mathrm{b}}$ & $45.0^{\mathrm{b}}$ & $25.5^{\mathrm{c}}$ \\
50 & $104.3^{\mathrm{a}}$ & $97.7^{\mathrm{a}}$ & $90.1^{\mathrm{a}}$ & $81.6^{\mathrm{a}}$ & $73.1^{\mathrm{a}}$ & $62.2^{\mathrm{a}}$ & $47.8^{\mathrm{a}}$ \\
100 & $103.8^{\mathrm{a}}$ & $95.6^{\mathrm{a}}$ & $87.2^{\mathrm{a}}$ & $75.5^{\mathrm{ab}}$ & $64.6^{\mathrm{a}}$ & $51.4^{\mathrm{b}}$ & $36.7^{\mathrm{b}}$
\end{tabular}

Values are the means of 4 replicates. Least significant difference was used for data analyzing. Superscript letters are represented significant differences (at $P=0.01$ ). Same letters in each day show that there are not significant differences among treatment levels.

One of NO roles in plants is chlorophyll production (Bowyer et al., 2003). Internal NO has positive effect on chlorophyll content of leaves. NO increased chlorophyll content of guard cells in pea leaves (Leshem \& Wills, 1998). Spraying of wheat seedlings with SNP resulted in 30-40\% more chlorophyll content (Beligni \& Lamattina, 2000).

In this experiment total chlorophyll content (chlorophyll $\mathrm{a}+\mathrm{b}$ ) did not show significant differences among treatment levels (Figure 3). It means that SNP application could not keep the total chlorophyll content. In phlox flowers at high SNP concentrations ( $>50 \mu \mathrm{M}$ ) the leaves became either yellow or more frequently turned black and senesced (Sankhla et al., 2003). SNP application was not effective on chlorophyll content of carnation (Dianthus caryophyllus 'Nelson') leaves when was applied alone (Mostofi et al., 2010).

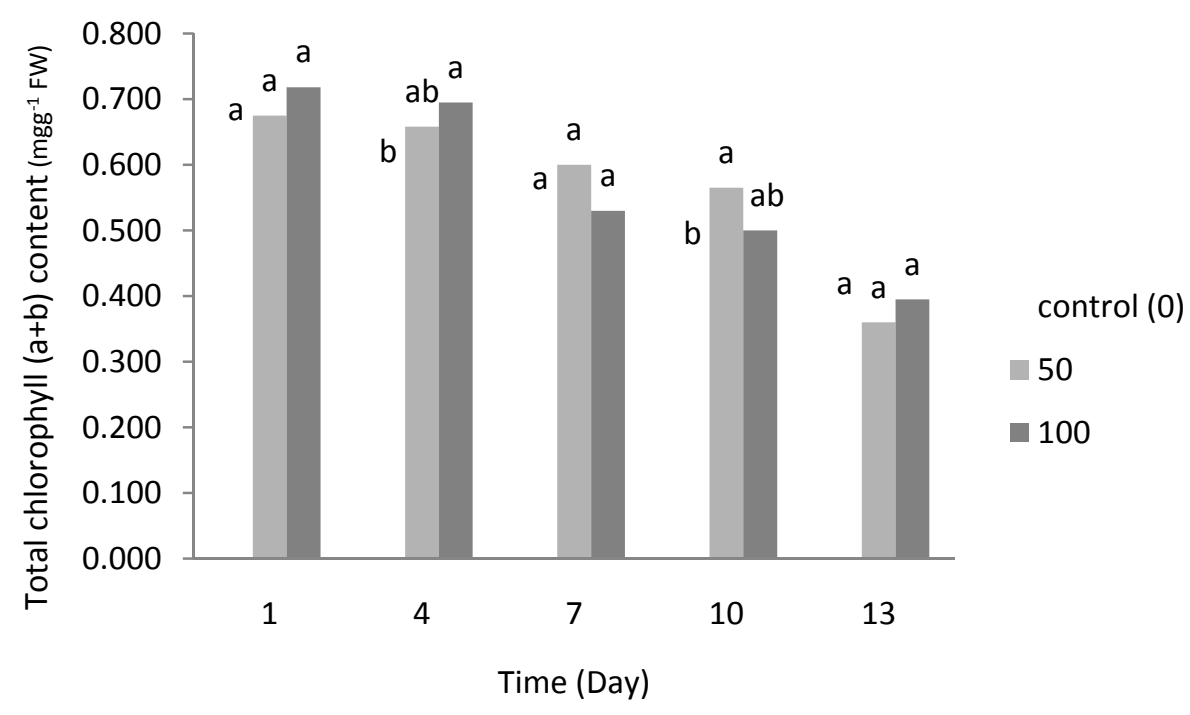

Figure 3. Effect of SNP (control= 0, 50, and $100 \mu$ Molar) on total chlorophyll content (chlorophyll $\mathrm{a}+\mathrm{b}$ ) (mg g ${ }^{-1} \mathrm{FW}$ ) of leaves of cut rose 'utopia'

Values are the means of 4 replicates. Least significant difference (LSD $P=0.01$ ) was used to compare differences between means. Same letters in each day show that there are not significant differences among treatment levels.

Depending on the concentration, NO donors exhibited differential response to No donors which ranged from almost no effect or a slight inhibition to a distinct promotion of flower senescence (Sankhla et al., 2003).

SNP (50 $\mu$ Molar) increased vase life of cut roses compared to control significantly (from 11 days to 13.3 days), whereas difference among vase life of control and SNP (100 $\mu$ Molar) treated flowers was not significant (Table 2). On the other hand, vase life of flowers which had been treated with two different concentrations of SNP was not significant. SNP (100 $\mu$ Molar) did not show any effect on senescence of lupin 'Pink Bulk' flowers (Sankhla et al., 2003). In another investigation DETA/NO had increased the vase life of eight flower species such as gerbera, tulip, iris, snapdragon, delphinium, oriental lily, rose and chrysanthemum (Badiyan et al., 2004). SNP concentrations 
less than $50 \mu$ Molar resulted in retarding the senescence of lupine (Lupinus densiflorus) flowers (Sankhla et al., 2005).

Table 2. Effect of SNP on vase life (days) of cut rose 'Utopia'.

\begin{tabular}{ccc}
\hline \multicolumn{3}{c}{ SNP $(\mu \mathrm{mol})$} \\
\hline Control & 50 & 100 \\
\hline $11^{\mathrm{b}}$ & $13.3^{\mathrm{a}}$ & $12.7^{\mathrm{ab}}$ \\
\hline
\end{tabular}

Values are the means of 4 replicates. Least significant difference was used for data analyzing. Superscript letters are represented significant differences (at $P=0.01$ ). Same letters show that there are not significant differences among treatment levels.

Application of DETA/NO (10 $\left.\mathrm{mgL}^{-1}\right)$ increased vase life of cut carnation (Dianthus caryophyllus 'White Sim' ) by $50 \%$ (Bowyer \& Wills, 2003). Also, DETA/NO (10,100, and $1000 \mathrm{ppm}$ ) increased postharvest life of three native Australian cut flowers such as waratah, kangaroo paw and ptilotus (Bowyer et al., 2003). Presence of nitric oxide free radical, suppresses ethylene biosynthesis by oxidative inactivating of ACC synthase (ACS) and ACC oxidase (ACO) co-factors and extends longevity of cut flowers (Leshem \& Wills, 1998; Mostofi et al., 2010). SNP (50 $\mu$ Molar) application as a NO donor compound resulted in keeping the relative fresh weight of flower stems by diminishing the rate of transpiration and slow down the water loss due to the stoma closure (Steven et al., 2003) and also by more solution uptake. SNP (50 $\mu$ Molar) as a NO donor compound kept soluble protein content of petals and retarded flower senescence. It has been proved that depletion of respiration precursors like proteins induces flower senescence (Halvey \& Mayak, 1981). In this work SNP (50 $\mu$ Molar) application could extend vase life of cut roses, but SNP (100 $\mu$ Molar) treated flowers did not have more vase life than control. It would appear that the beneficial or detrimental effects of NO donors may depend on concentration, and sensitivity of genotypes. High concentrations of NO may cause toxicity mainly due to its reaction with superoxide anion (Sankhla et al., 2003). On the other hand, application of NO in low concentrations as fumigation or NO donors is useful to increase postharvest life of cut flowers and other horticultural produces (Sankhla et al., 2005; Wills et al., 2004; Wills et al., 2003). It seems that the multiple modes of action of NO are suggestive of its wider modality than just on ethylene action (Sankhla et al., 2003). As a solid that dissolves in water and with effectiveness from a single initial application at a relatively low concentration, also because of its low price, SNP could be introduce to apply in cut flower trading to extend vase life of flowers. Further work is required to assess the mechanism of SNP effects on postharvest life of other cut rose flower cultivars.

\section{References}

Arasimowicz, M., \& Floryszak-Wieczorek, J. (2007). Nitric oxide as a bioactive signaling molecule in plant stress responses. Plant Science, 172, 876- 887. http://dx.doi.org/10.1016/j.plantsci.2007.02.005

Badiyan, D., Wills, R. B. H., \& Bowyer, M. C. (2004). Use of nitric oxide donor compound to extend the vase life of cutflowers. HortScience, 39(6), 1371-1372.

Beligni, M. W., \& Lamattina, L. (2000). Nitric oxide stimulates seed germination and de-etiolation, and inhibits hypocotyl elongation, three light-inducible responses in plants. Planta, 210, 215-221. http://dx.doi.org/10.1007/PL00008128

Bowyer, M. C., \& Wills, R. B. H. (2003). Delaying postharvest senescence of cut flowers using nitric oxide (pp. 1-11). Rural Industries Research \& Development Corporation, Kingston.

Bowyer, M. C., Wills, R. B. H., Badiyan, D., \& Ku, V. V. V. (2003). Extending the postharvest life of carnation with nitric oxide comparison of fumigation and in vivo delivery. Postharvest Biology and Technology, 30(3), 281-286. http://dx.doi.org/10.1016/S0925-5214(03)00114-5

Bradford, M. M. (1976). A rapid and sensitive method for the quantitation of microgram quantities of protein utilizing the principle of protein dye-binding. Analytical Biochemistry, 72, $248-254$. http://dx.doi.org/10.1016/0003-2697(76)90527-3

Butler, R. A., \& Megson, I. L. (2002). Non-heme iron nitrosyls in biology. Chemical Reviews, 102(4), $1155-1165$. http://dx.doi.org/10.1021/cr000076d 
Cevahir, G., Aytamka, E., \& Erol, Ç. (2007). The role of nitric oxide in plants. Biotechnology \& Biotechnological Equipment, 21(1), 13-17.

Chamani, E. (2005). The effect of thidiazuron, 1-methylcyclopropene, nitric oxide, and ethylene on physicochemical traits of cut rose flowers (pp. 1- 250). [Ph.D. Thesis.], University of Tehran, Iran.

Chamani, E., Khalighi, A., Joyce, D. C., Irving, D. E., Zamani, Z. A., Mostofi, Y., \& Kafi, M. (2005). Ethylene and anti-ethylene treatment effects on cut 'First Red' rose. Journal of Applied Horticulture, 7(1), 3-7.

Corpas, F. J., Barroso, J. B., \& Del Rio, L. A. (2001). Peroxisomes as a source of reactive oxygen species and nitric oxide signal molecules in plant cells. Trends in Plant Science, 6(4), 145-150. http://dx.doi.org/10.1016/S1360-1385(01)01898-2

Crawford, N. M. (2006). Mechanisms for nitric oxide synthesis in plants. Journal of Experimental Botany, 57(3), 471- 478. http://dx.doi.org/10.1093/jxb/erj050

Del Rio, L. A., Corpas, F. J., \& Barroso, J. B. (2004). Molecules of interest nitric oxide and nitric oxide synthase activity in plants. Phytochemistry, 65, 783-792.

Ferrante, A., Hunter, D. A., Hackett, W. P., \& Reid, M. S. (2002). Thidiazuron a potent inhibitor of leaf senescence in alsteromeria. Postharvest Biology and Technology, 25, 333-338. http://dx.doi.org/10.1016/S0925-5214(01)00195-8

Finger, F. L., Campanha, M. M., Barbosa, J. G., \& Fontes, P. C. R. (1999). Influence of ethephone, silver thiosulfate, and sucrose pulsing on bird of paradise vase life. Revista Brasileira de Fisiologia Vegetal, 11(2), $119-122$.

Garcia, M. C., \& Lamattina, L. (2003). Abscisic acid, nitric oxide, and stomatal closure - is nitrate reductase one of the missing links. Trends in Plant Science, 8(1), 20-26. http://dx.doi.org/10.1016/S1360-1385(02)00009-2

Garello, G., Mc Nard, C., Dansereau, B., \& Le Page Degivry, M. T. (1995). The influence of light quality on rose flower senescence: involvement of abscisic acid. Plant Growth Regulation, 16(2), 135-139. http://dx.doi.org/10.1007/BF00029534

Gulzar, S., Tahir, I., Amin, I., Frooq, S., \& Sultan, S. M. (2005). Effect of cytokinins on the senescence and longevity of isolated flowers of day lily (Hemerocallis fulva cv. Royal Crown) sprayed with cyclohexamide. Acta Horticulturae, 669, 395-403.

Halvey, A. H., \& Mayak, S. (1979). Senescence and postharvest physiology of cut flowers. Part 1.Horticultural Review, 1, 204-234. http://dx.doi.org/10.1002/9781118060742.ch5

Halvey, A. H., \& Mayak, S. (1981). Senescence and postharvest physiology of cut flowers. Part 2. Horticultural Review, 3, 59-143. http://dx.doi.org/10.1002/9781118060766.ch3

Hashemabadi, D., \& Gholampour, A. (2006). The effective factors on postharvest life of cut flowers (Carnation). In: Papers of National Symposium for Improving Ornamental Plant and Flower Production and Export Development of Iran (pp. 131-139).

Heyes, J. A., \& Johnston, J. W. (1998). 1-Methylcyclopropene extends cymbidium orchid vase life and prevents damaged pollinia from accelerating senescence. New Zealand Journal of Crop and Horticultural Science, 26(4), 319-324.

Ichimura, K., Shimizu, H., Hiraya, T., \& Hisamatsu, T. (2002). Effect of 1-methylcyclopropene (1-MCP) on vase life of cut carnation, delphinium, and sweet pea flowers. Bulletin of National Institute of Floricultural Science, $2,1-8$.

Jones, M. L., Sun, K. E., \& Newman, S. E. (2001). Role of ethylene and 1-MCP in flower development and petal abscission in zonal geraniums. HortScience, 36(7), 1305-1309.

Leshem, Y. Y., \& Wills, R. B. H. (1998). Harnessing senescence delaying gases nitric oxide and nitrous oxide: a novel approach to postharvest control of fresh horticultural produce. Biologia Plantarum, 41(1), 1-10.

Liao, L. J., Haung, K. L., Chen, W. S., \& Cheng, Y. M. (2000). Postharvest life of cut rose flowers as affected by silver thiosulfate and sucrose. Botanical Bulletin Academica Sinica, 41, 299- 303.

Mayers, A., Newman, J., Reid, M., \& Dodge, L. (1997). New ethylene inhibitor could extend flower life. Perishables Handling Quarterly, 92, 9-11. 
Mostofi, Y., Rasouli, P., Naderi, R., Bagheri Marandi, G. H., \& Shafiei, M. R. (2010). Effect of nitric oxide and thidiazuron on vase life and some qualitative characteristics of cut carnation flowers (Dianthus caryophyllus cv. Nelson). Iranian Journal of Horticultural Science, 41(4), 301- 308.

Rudell, D. R., \& Matheis, J. P. (2006). Nitric oxide and nitrite treatments reduce ethylene evolution from apple fruit disks. Hort Science, 41(6), 1462-1465.

Sankhla, N., Mac Kay, W. A., \& Davis, T. D. (2003). Effect of nitric oxide on postharvest performance of perennial phlox cut inflorescences. Acta Horticulturae, 628, 843-847.

Sankhla, N., Mac Kay, W. A., \& Davis, T. D. (2005). Effect of nitric oxide generating compounds on flower senescence in cut racemes of pink flowered Lupinus havardii Wats. In: Proceedings of Plant Growth Regulation. Society of America-Annual Meeting, 32, 126-132.

Särkkä, L. (2005). Yield, quality, and vase life of cut roses in year round greenhouse production (pp. 1- 64). [Academic Thesis]. University of Helsinki. Finland.

Serek, M., \& Reid, M. S. (1997). Use of growth regulators for improving postharvest quality of ornamentals. Perishable Handling Quarterly, 92, 7-9.

Serek, M., Sisler, E. C., Frello, S., \& Srisk, S. (2006). Postharvest technologies for extending the shelf life of ornamental crops. International Journal of Postharvest Technology and Innovation, 1(1), 69-75. http://dx.doi.org/10.1504/IJPTI.2006.009184

Soegiarto, L., Wills, R. B. H., Seberry, J. A., \& Leshem, Y. Y. (2003). Nitric oxide degradation in oxygen atmospheres and rate of uptake by horticultural produce. Postharvest Biology and Technology, 28(2), 327-331. http://dx.doi.org/10.1016/S0925-5214(02)00199-0

Steven, J. N., Desikan, R., \& Hancock, J. T. (2003). Nitric oxide signaling in plants. New Phytologist, 159(1), 11-35. http://dx.doi.org/10.1007/7089_2006_093

Thomas, D. D., Ridnour, L. A., Isenberg, J. S., Flores-Santana, W., Switzer, C. H., Donzelli, S., ... Wink, D. A. (2008). The chemical biology of nitric oxide: Implications in cellular signaling. Free Radical Biology and Medicine, 45, 18- 31. http://dx.doi.org/10.1016/j.freeradbiomed.2008.03.020

Tongfei, L., Yuying, W., Boqiang, L., Guozheng, Q., \& Shiping, T. (2011). Defence responses of tomato fruit to exogenous nitric oxide during postharvest storage. Postharvest Biology and Technology, 62, 127- 132.

Wills, R. B. H., Ku, V. V. V., \& Leshem, Y. Y. (2000). Fumigation with nitric oxide to extend the postharvest life of strawberries. Post harvest Biology and Technology, 18(1), 75-79. http://dx.doi.org/10.1016/S0925-5214(99)00061-7

Wills, R. B. H., Bowyer, M. C., \& Leshem, Y. Y. (2003). Use of nitric oxide to extend the postharvest life ofhorticultural produce. Acta Horticulturae, 599, 519-521.

Wills, R. B. H., Bowyer, M. C., \& Badiyan, D. (2004). Use of nitric oxide donor compound to extend the vase life of cut flowers. Horticulture Science, 39(6), 1371-1372. 